\title{
HEINONLINE
}

Citation: 81 U. Chi. L. Rev. 3612014

Provided by:

The University of Chicago D'Angelo Law Library

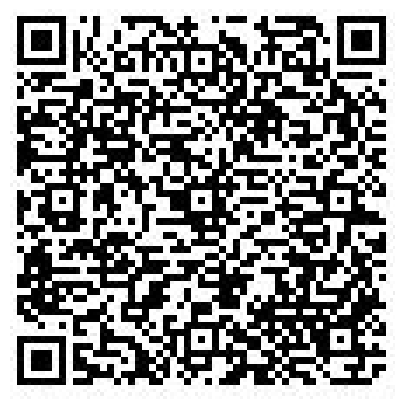

Content downloaded/printed from

HeinOnline (http://heinonline.org)

Tue Feb 2 13:06:32 2016

-- Your use of this HeinOnline PDF indicates your acceptance of HeinOnline's Terms and Conditions of the license agreement available at http://heinonline.org/HOL/License

-- The search text of this PDF is generated from uncorrected OCR text.

-- To obtain permission to use this article beyond the scope of your HeinOnline license, please use:

https://www.copyright.com/ccc/basicSearch.do?

\&operation $=$ go\&search Type $=0$

\&lastSearch $=$ simple\&all $=$ on\&titleOrStdNo $=0041-9494$ 


\title{
COMMENT
}

\section{Too Late to Stipulate: Reconciling Rule 68 with Summary Judgments}

\author{
Channing J. Turner†
}

\section{INTRODUCTION}

Imagine a typical lawsuit between two parties, plaintiff and defendant. The litigants have reached the final days of pretrial litigation, and like any good defense counsel, the defendant's lawyer hopes to dismiss the case before going to trial. He moves for summary judgment-increasingly common in modern litigation ${ }^{1}$-and raises the possibility of settlement with the plaintiff. Hoping to strong-arm an end to the case, he decides to send the plaintiff a special settlement offer under Federal Rule of Civil Procedure 68 called an "offer of judgment." If the plaintiff accepts this offer, the court will automatically enter judgment against the defendant according to the offer's terms. The case will end. But if the plaintiff declines the offer, Rule 68 may make the plaintiff liable for costs that the defendant incurs during subsequent litigation. ${ }^{2}$ This risk of increased costs means the plaintiff should think seriously about accepting the offer.

Before the plaintiff makes a decision, however, the judge grants full summary judgment for the defendant. The plaintiff has lost-at least in the eyes of the court. But plaintiff's counsel sees an opportunity to turn things around. As soon as he learns of the summary judgment ruling, the plaintiff contacts the defendant to accept his offer of judgment. The defendant protests, but the plaintiff points out that the Rule makes no exception for

$\dagger$ BA 2011, Arizona State University; MMC 2011, Arizona State University; JD Candidate 2014, The University of Chicago Law School.

1 See Paul W. Mollica, Federal Summary Judgment at High Tide, 84 Marq L Rev 141, 143-44 (2000) (reporting that, in a limited sample of twenty volumes of the Federal Reporter from 1973 and 1997-98, the proportion of cases terminating in summary judgment increased from about fourteen per volume in 1973 to forty-seven per volume in 1997-98).

2 FRCP 68(d). 
a grant of summary judgment. At the same time, plaintiff sends the court notification of the offer and his acceptance, along with a motion to amend the entry of summary judgment and enter final judgment against the defendant. If the court grants his motion, the plaintiff has succeeded in turning a certain defeat into a victory.

This hypothetical illustrates the dilemma facing courts that grant summary judgment during a pending offer of judgment. Rule 68 is a rigid procedural mechanism. Once made, the litigants cannot revoke a Rule 68 offer. And once accepted, the Rule appears to mandate entry of judgment. The plaintiff ${ }^{3}$ has fourteen days to accept an offer before it is considered withdrawn, ${ }^{4}$ and if the plaintiff accepts during this period, the court clerk "must" enter judgment according to the defendant's terms. ${ }^{5}$

This language has caused a split in federal and state courts as to whether a grant of summary judgment during the fourteen-day acceptance period ends the plaintiff's power to accept an offer or whether a plaintiff can still accept even after summary judgment has been granted. The implications of this issue for litigants and our adversarial system are significant. If a plaintiff can accept an offer of judgment even after the case would otherwise end in summary judgment, then he can essentially win his case despite having lost on the merits.

This Comment begins with the intuition that something about the entry of judgments makes it different from all other events that might occur during an outstanding Rule 68 offer. Unlike, say, the death of a witness or a ruling on the exclusion of evidence, the operation and purposes of Rule 68 suggest that it should afford special significance to an order disposing of the case.

Accordingly, this Comment advances two ideas: First, offer and acceptance in Rule 68 should be viewed as procedural, rather than contractual. And second, entry of final judgment, but not necessarily summary judgment, should abrogate the operation of Rule 68. To get there, Part I introduces Rule 68 by explaining its operation and its drafters' possible intent. Part II introduces the conflict between Rule 68 and summary judgment

3 Rule 68 uses the terms "party defending against a claim" and "opposing party" in order to include counterclaims, cross claims, and third-party claims. FRCP 68(a). Con. sistent with the existing literature, this Comment simply refers to "plaintiff" and "de. fendant" to distinguish between the party bringing a claim and the party defending a claim, whether or not that party would be the actual plaintiff or defendant at trial.

4 FRCP 68(b).

5 FRCP 68(a). 
and charts the approaches courts take in interpreting Rule 68 and similar state rules. Part III proposes a new procedural conception of offer and acceptance in the context of Rule 68. It shines a finer light on the ubiquitous yet easily confused court orders called "judgments" in order to distinguish summary judgment from its more procedurally significant counterpart, final judgment. It then leverages the standard for amending judgments to argue that final judgment nullifies a Rule 68 offer. Finally, Part III ends by explaining how this interpretation promotes the purposes and operation of Rule 68 .

\section{RULE 68's PURPOSE AND PROBLEMS}

Before launching into interpretation, it's important to understand why Rule 68 comes into conflict with the law of judgments. This Part begins by explaining Rule 68's operation and the historical context that guides courts in interpreting it. Then, it describes Rule 68's doctrine of irrevocability and how courts have conceptualized the Rule's offer-acceptance procedure in light of the Rule's textual ambiguity.

\section{A. "The Most Enigmatic of the Federal Rules"6}

At first glance, Rule 68 appears fairly simple. ${ }^{7}$ Rule 68 allows a defendant-but not a plaintiff ${ }^{8}$ - to serve an offer on the plaintiff to settle a case for a certain dollar amount or other relief. If the plaintiff decides to accept the offer within fourteen days, either party can file the offer, notice of acceptance, and proof of the original service with the court. ${ }^{9}$ Until this point, the court has no involvement in - and may not even know aboutthe offer. Once filed, the court then enters judgment according to the offer's terms. ${ }^{10}$ However, if the plaintiff does not accept the offer and subsequently wins a judgment "not more favorable

6 Crossman v Marcoccio, 806 F2d 329, 331 (1st Cir 1986).

7 FRCP 68(a) states:

At least 14 days before the date set for trial, a party defending against a claim may serve on an opposing party an offer to allow judgment on specified terms, with the costs then accrued. If, within 14 days after being served, the opposing party serves written notice accepting the offer, either party may then file the offer and notice of acceptance, plus proof of service. The clerk must then enter judgment.

8 See FRCP 68(a) (allowing "a party defending against a claim" to make an offer of judgment but giving no comparable power to a party bringing a claim).

9 FRCP 68(a).

10 FRCP 68(a). 
than the unaccepted offer," the plaintiff must pay all costs incurred by the defendant after the offer was made.11

Despite this apparent simplicity, Rule 68 has been described as "among the most enigmatic of the Federal Rules of Civil Procedure,"12 in large part because it leaves many basic questions unanswered. For example, what expenses qualify as "costs"? For the most part, the costs of litigation in Rule 68 have been interpreted similarly to other areas of the Federal Rules. ${ }^{13}$ However, the Supreme Court significantly upped the ante in Marek $v$ Chesny ${ }^{14}$ by holding that costs under Rule 68 also include any expense labeled as "costs" in the substantive statute underlying a lawsuit, making those costs orders of magnitude higher in cases that involve a substantive fee-shifting statute..$^{15}$

Plenty of other questions surrounding Rule 68 still have no clear answer. For example, are offers that disclaim liability invalid? ${ }^{16}$ May a defendant ever revoke an offer before the fourteen-day acceptance period lapses? ${ }^{17}$ Must offers provide for the relief requested in the plaintiff's complaint? ${ }^{18}$ And how should courts construe offers when the defendant leaves the scope of proffered recovery ambiguous? ${ }^{19}$

History provides good reason to think that these ambiguities will not be easily resolved through revision or amendment.

11 FRCP 68(d).

12 Crossman, 806 F2d at 331. See also Danielle M. Shelton, Rewriting Rule 68: Realizing the Benefits of the Federal Settlement Rule by Injecting Certainty into Offers of Judgment, 91 Minn L Rev 865, 876-921 (2007) (canvassing the many areas of uncertainty in interpreting and applying Rule 68).

13 See Marek v Chesny, 473 US 1, 13-14 (1985) (Brennan dissenting) (asserting that "costs" under Rule 68 have traditionally been interpreted as those taxable costs defined in 28 USC $\S 1920$, including "court fees, printing expenses, and the like").

14473 US 1 (1985).

15 Id at 9. See also Christopher W. Carmichael, Encouraging Settlements Using Federal Rule 68: Why Non-prevailing Defendants Should Be Awarded Attorney's Fees, Even in Civil Rights Cases, 48 Wayne L Rev 1449, 1455-58 (2003) (describing the interaction between Rule 68 and substantive statutes that include a shifted duty to pay attorney's fees).

16 See Shelton, 91 Minn L Rev at 881-83 (cited in note 12) (finding that, despite near uniformity of agreement that a valid offer of judgment can disclaim liability, some courts continue to reject such offers, creating "continuing uncertainty and resulting [in] collateral litigation").

17 See id at 883-86 (outlining the split between cases that find Rule 68 offers "categorically" irrevocable and cases that leave open the possibility of revocation under limited circumstances).

18 See id at 886-88 (describing confusion over whether an offer that provides only injunctive relief when money damages are sought is valid).

19 See id at 888-915 (canvassing cases in which confusion exists over whether the defendant intended to include attorney's fees and whether the amount of the defendant's offer includes costs then accrued). 
Multiple efforts to amend the Rule have failed. In 1983-84, an effort to change the Rule provoked intense controversy that ultimately led to abandonment of the suggested amendments. ${ }^{20}$ Another effort in 1992-93 fared no better. ${ }^{21}$

In the face of all this uncertainty, it's natural to turn to Rule 68 's purpose as a guide for interpretation. However, understanding Rule 68's purpose presents problems of its own. The Supreme Court has said that Rule 68 was adopted to "encourage settlement and avoid litigation" by "prompt[ing] both parties to a suit to evaluate the risks and costs of litigation, and to balance them against the likelihood of success upon trial on the merits." 22 Thus, courts have universally accepted settlement promotion as the Rule's guiding principle. ${ }^{23}$

Yet, judges, lawyers, and commentators alike doubt the Rule's ability to actually promote settlement. ${ }^{24}$ When the Advisory Committee on the Civil Rules proposed amendments to the Rule in 1983, it acknowledged that the Rule "rarely has been invoked and has been considered largely ineffective as a means of achieving its goals." ${ }_{25}$ Commentators have speculated that the ambiguities left unresolved by the Rule's text undermine its purpose by discouraging litigants from utilizing it. ${ }^{26}$ A survey of

20 See Roy D. Simon Jr, The Riddle of Rule 68, 54 Geo Wash L Rev 1, 12-19 (1985) (describing the efforts of defense lawyers to promote the proposed amendment and opposition from the plaintiff's bar and civil rights lawyers).

21 See Lesley S. Bonney, Robert J. Tribeck, and James S. Wrona, Rule 68: Awakening a Sleeping Giant, 65 Geo Wash L Rev 379, 380-81 (1997) (describing Rule 68's descent into obscurity and the renewed attention it received from efforts to revise it in the 1990s); David A. Anderson and Thomas D. Rowe Jr, Empirical Evidence on Settlement Devices: Does Rule 68 Encourage Settlement?, 71 Chi Kent L Rev 519, 519 n 2 (1995).

22 Marek, 473 US at 5 (describing the Court's interpretation of Rule 68's purpose). See also Delta Air Lines, Inc v August, 450 US 346, 352 (1981) ("The purpose of Rule 68 is to encourage the settlement of litigation."). But see Robert G. Bone, "To Encourage Settlement": Rule 68, Offers of Judgment, and the History of the Federal Rules of Civil Procedure, $102 \mathrm{Nw}$ U L Rev 1561, 1566 (2008) ("[T] here is a serious problem with this view of Rule 68.").

23 See, for example, Perkins v US West Communications, 138 F3d 336, 338 (8th Cir 1998) (stating that " $[t]$ he purpose of Rule 68 is to promote the compromise and settlement of litigation"), citing Delta Air Lines, 450 US at 352 n 8.

24 See Simon, 54 Geo Wash L Rev at 6-7 (cited in note 20) ("Many lawyers and judges believe that rule 68 has failed to encourage settlement."). For an empirical study of whether Rule 68 encourages settlement, see generally Anderson and Rowe, $71 \mathrm{Chi}$ Kent L Rev 519 (cited in note 21).

25 Committee on Rules of Practice \& Procedure of the Judicial Conference of the United States, Preliminary Draft of Proposed Amendments to the Federal Rules of Appellate Procedure, Federal Rules of Civil Procedure, Federal Rules of Criminal Procedure, and Rules Governing Section 2254 Cases and Section 2255 Proceedings in the United States District Courts, 102 FRD 407, 433 (1984).

26 See Shelton, 91 Minn L Rev at 921 (cited in note 12) ("[T]he rule's lack of clarity with regard to offers undermines its very purpose."); Keith N. Hylton, Rule 68, the Modified 
practicing civil rights and employment-discrimination attorneys published in 2007 provides anecdotal confirmation that uncertainties can make Rule 68 unattractive. ${ }^{27}$

Notwithstanding its critics, there is reason to think Rule 68 has evolved into a potent strategic tool in specific situations. Marek transformed Rule 68 into a "powerful settlement weapon" in cases that involve attorney's-fee-shifting provisions. ${ }^{28}$ For example, civil rights cases commonly involve fee-shifting provisions that lump attorney's fees under "costs" awarded to a prevailing plaintiff. ${ }^{29}$ Looking beyond dollars and cents, Rule 68 has also been used strategically to knock out the named plaintiff in class action lawsuits-a controversial practice that the Supreme Court recently declined to address in Genesis HealthCare Corp $v$ Symczyk..$^{30}$ And a Rule 68 acceptance following an adverse summary judgment-this Comment's topic-also has significant strategic implications.

Faced with the broad uncertainty and increasing strategic importance of Rule 68 , it seems inevitable that courts would encounter procedural conflicts between Rule 68 and other Federal Rules. One of the most striking of these-and one this Comment hopes to clarify-is a conflict between the way courts have interpreted the mechanics of Rule 68 and the typical operation of summary judgment.

\section{B. The Leap from Irrevocable Offers to Option Contracts}

While it might seem natural to abrogate a rule concerning settlement when the court grants summary judgment, a principal tenet of Rule 68's interpretation complicates the calculation: the irrevocability of an offer of judgment. Most litigation over Rule 68 has tackled the question of whether an offer can be

\footnotetext{
British Rule, and Civil Litigation Reform, 1 Mich L \& Pol Rev 73, 97 (1996) (concluding that fee-shifting and penalization schemes like Rule 68 are unlikely to encourage settlement).

27 See Harold S. Lewis Jr and Thomas A. Eaton, Rule 68 Offers of Judgment: The Practices and Opinions of Experienced Civil Rights and Employment Discrimination Attorneys, 241 FRD 332, 350-56 (2007) (suggesting reasons for Rule 68's underuse, including uncertainty about whether judgments reached through Rule 68 could include a nonadmission-of-liability clause).

28 See Simon, 54 Geo Wash L Rev at 23 (cited in note 20) (claiming that Marek "transformed rule 68 into a powerful settlement weapon").

29 See Lewis and Eaton, 241 FRD at 333-34 (cited in note 27) (noting that the "great bulk of contemporary federal question litigation is founded on statutes that do award fees as part of costs," including most civil rights legislation, Title VII of the Civil Rights Act of 1964, and many environmental statutes).

$30133 \mathrm{~S} \mathrm{Ct} 1523,1526$ (2013) (declining to decide the merits after holding that the plaintiff's case was moot).
} 
revoked by the defendant before the end of the statutory time period for acceptance. ${ }^{31}$ The text of Rule 68 allows acceptance "within 14 days after being served," 32 but it makes no mention of a defendant's power of revocation or whether other events may destroy the plaintiff's power of acceptance. On the other hand, the Rule is unequivocal in instructing the court to enter judgment upon notification of acceptance within fourteen days. ${ }^{33}$ The implications of this language have almost universally persuaded courts to make offers of judgment irrevocable during the fourteen-day period, although they differ on whether offers are "categorically" irrevocable or can be revoked under certain exceptional circumstances. ${ }^{34}$

Typically, the defendant seeks to revoke an offer only if he discovers some error after having made it. This was the case in Fisher $v$ Stolaruk Corp ${ }^{35}$ when the defendant attempted to rescind his offer of judgment after his attorney failed to realize that the term "costs" under Rule 68 does not include attorney's fees unless they are additionally provided for in the agreement. ${ }^{36}$ The defendant attempted to add attorney's fees to his offer, but the plaintiff interpreted the attempt as an impermissible withdrawal and purported to accept the existing terms. ${ }^{37}$ The Fisher court held that a mistake of law made by one party that the other party knows about-or should have known about-warranted allowing withdrawal by the defendant. ${ }^{38}$

However, most courts conclude that they have no discretion to prevent entry of judgment upon acceptance of the offer. In Richardson $v$ National Railroad Passenger Corp, ${ }^{39}$ the court

31 See Wersch v Radnor/Landgrant-A Phoenix Partnership, 961 P2d 1047, 1049 n 3 (Ariz App 1997) ("The majority of litigation involving Rule 68 centers on whether offers of judgment can be withdrawn or revoked.").

32 FRCP 68(a).

33 FRCP 68(a).

34 Compare Richardson v National Railroad Passenger Corp, 49 F3d 760, 765 (DC Cir 1995) (holding "categorically" that "a Rule 68 offer is simply not revocable during the 10-day period"), with Fisher v Stolaruk Corp, 110 FRD 74, 76 (ED Mich 1986) (holding that defendant is entitled to rescind a Rule 68 offer when the offer was made under a mistaken interpretation of law).

$35 \quad 110$ FRD 74 (ED Mich 1986).

36 Id at 75 .

37 Id.

38 Id at 76 (explaining that the defendant had satisfied the four technical requirements to allow rescission: (1) the mistake must make enforcement unconscionable, (2) the mistake must be material, (3) the mistake must have occurred despite the exercise of ordinary care, and (4) the other party must be able to return to the position of the status quo ante).

$39 \quad 49$ F3d 760 (DC Cir 1995). 
squarely rejected a defendant's attempt to revoke an offer of judgment during the statutory period of acceptance. The defendant allegedly discovered information that discredited medical testimony regarding the nature of the plaintiff's injuries. ${ }^{40}$ The court held "categorically" that "a Rule 68 offer is simply not revocable" during the statutory period. ${ }^{41}$ The Ninth Circuit in Erdman $v$ Cochise County, Arizona ${ }^{42}$ also did not allow revocation when the defendant failed to recognize that "costs" in the context of a 42 USC $\S 1983$ case automatically include attorney's fees post-Marek. ${ }^{43}$ Instead, the court reversed a grant of withdrawal and forced the defendant to pay attorney's fees in the amount agreed. ${ }^{44}$

In Mallory $v$ Eyrich, ${ }^{45}$ the defendant attempted a slightly different strategy that, while not truly an attempt to revoke, could be thought of as an attempt to achieve the same result. Instead of trying to withdraw the offer, the defendant sought relief from the judgment entered against him. ${ }^{46}$ Characterizing Rule 68 as "self-executing," the Sixth Circuit concluded that "the court has no discretion to withhold its entry or otherwise to frustrate the agreement." 47 The court reasoned that the offer of judgment's special cost-shifting mechanism makes a judgment resulting from it less amenable to change or abrogation. ${ }^{48}$ Ultimately, the court upheld the judgment, concluding that the defendant had not presented a sufficient basis to afford relief. ${ }^{49}$

The question of when a defendant may revoke an offer has led many courts and commentators to compare Rule 68 with a contractual tool that also prevents withdrawal: the option contract. Under general principles of contract law, an offer made by one party generally gives the second party the power to accept that offer and create a binding contract unless it is revoked

40 Id at 762 .

41 Id at 765 .

42926 F2d 877 (9th Cir 1991).

43 Id at 879 .

44 Id at 883 .

45922 F2d 1273 (6th Cir 1991).

46 Id at $1275-76$.

47 Id at 1279 .

48 Id at 1280 ("Its unique characteristics-a cost-shifting provision and absence of court discretion in implementation-make such a judgment less amenable to change or abrogation than an ordinary consent judgment.").

49 Mallory, 922 F2d at 1280-81 (surveying the six grounds for relief under Rule 60 (b) as well as Supreme Court clarification of the Rule and concluding that the defendant failed to state adequate grounds for relief). 
before acceptance occurs.50 A promise that meets the requirements of a contract and limits the offeror's power to revoke for a defined period of time constitutes an option contract, ${ }^{51}$ giving the offeree a guaranteed power to accept those terms during an allotted period of time. ${ }^{52}$ Thus, by many interpretations, Rule 68 operates like an option contract.

In Fisher, for example, the court held that offers of judgment should be governed by background contract principles and that such offers are therefore revocable when a mistake is made. ${ }^{53}$ Similarly, in Colonial Penn Insurance Co $v$ Coil,,$^{54}$ the Fourth Circuit held that an offer could be withdrawn when it was induced by fraud ${ }^{55}$-an easily recognizable contract principle. ${ }^{56}$ The Richardson court also explicitly endorsed the optioncontract comparison. ${ }^{57}$ Accordingly, Rule 68 has developed a reputation for walking and talking like a contract, and most courts regularly equate the two. ${ }^{58}$

\section{RULE 68'S CLASH WITH SUMMARY JUDGMENT}

Courts that grant summary judgment for the defendant but are asked to enforce an accepted offer of judgment face a unique dilemma: the court has determined that one party is entitled to judgment as a matter of law, while the parties have procedurally mandated the opposite conclusion. This Part describes the current

50 See Restatement (Second) of Contracts $§ 35(1)$ (1981) ("An offer gives to the offeree a continuing power to complete the manifestation of mutual assent by acceptance of the offer."); id at $\$ 36(1)$ ("An offeree's power of acceptance may be terminated by (a) rejection or counter-offer by the offeree, or (b) lapse of time, or (c) revocation by the offeror, or (d) death or incapacity of the offeror or offeree.").

51 See id at $\S 25$.

52 See Richard A. Lord, 1 Williston on Contracts $\S 5: 16$ at 1022 (West 4 th ed 2012) ("The traditional view regards an option as a unilateral contract which binds the optionee to do nothing, but grants him or her the right to accept or reject the offer in accordance with its terms within the time and in the manner specified in the option.").

53 Fisher, 110 FRD at 76.

54887 F2d 1236 (4th Cir 1989).

55 Id at 1240.

56 See Restatement (Second) of Contracts $\S 162(1)$ (1981).

57 Richardson, $49 \mathrm{~F} 3 \mathrm{~d}$ at 765 ("[T]he plaintiff, as we understand the scheme, is guaranteed 10 days to ponder the matter (as though the plaintiff had paid for a 10-day option).").

58 See Charles Alan Wright, Arthur R. Miller, and Richard L. Marcus, 12 Federal Practice and Procedure $\$ 3002$ at 94 (West 2d ed 1997 \& Supp 2013) ("As a general matter, it is agreed that since Rule 68 offers are basically offers of settlement their provisions should be interpreted according to contract law principles."). But see Shorter v Val. ley Bank \& Trust Co, 678 F Supp 714, 719 (ND Ill 1988) ("[T] he arrangement here is not a simple contract; it involves an accepted offer of judgment, and there is a difference."). 
legal landscape of courts attempting to reconcile this conflictwith wildly divergent results.

\section{A. Courts Allowing Rule 68 to Override Summary Judgment}

In Perkins $v$ US West Communications, ${ }^{59}$ the Eighth Circuit concluded that the power to accept a Rule 68 offer remains open notwithstanding summary judgment. ${ }^{60}$ The dispute in Perkins fits perfectly into the template for a conflict between offer of judgment and summary judgment. Prior to trial, US West Communications moved for summary judgment in a Title VII sex-discrimination case against it. ${ }^{61}$ While the judgment was pending, and before a trial date had been set, US West Communications also made a Rule 68 offer of judgment. ${ }^{62}$ Two days later, and without knowledge of the offer, the district court granted summary judgment and filed a separate final judgment dismissing plaintiff's complaint.63 When the plaintiff learned about the entry of judgment, plaintiff filed a notice of acceptance of the offer of judgment and moved to amend the court's earlier judgment in favor of the defendant. ${ }^{64}$ The district court granted the motion, awarding plaintiff the terms set forth in defendant's offer. ${ }^{65}$

The Eighth Circuit affirmed. ${ }^{66}$ The court turned first to Rule 68 's role in the promotion of settlements. It reasoned that the Rule prompts both parties to evaluate the risks and costs of litigation and to balance them against the likelihood of success. ${ }^{67}$ Thus, the defendant's offer amounted to a strategic decision that had consequences he or she must accept. ${ }^{68}$ The defendant also failed to condition acceptance of the offer on the outcome of the motion for summary judgment, the court noted.69

The court also determined that the plain language of Rule 68 mandates recognition of a plaintiff's acceptance. By saying

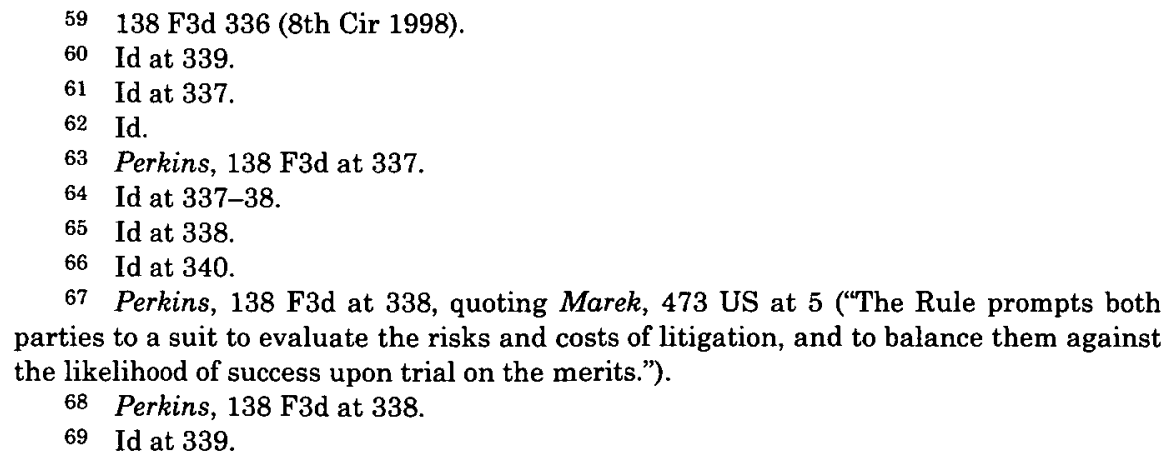

Perkins, 138 F3d at 338, quoting Marek, 473 US at 5 ("The Rule prompts both parties to a suit to evaluate the risks and costs of litigation, and to balance them against the likelihood of success upon trial on the merits.").

68 Perkins, 138 F3d at 338.

69 Id at 339 . 
that the clerk "shall" enter judgment, ${ }^{70}$ the Rule leaves no room for interference by the court to alter or modify the parties' agreement. ${ }^{71}$ The only exception to this mandatory procedure, the court reasoned, occurs if the deal contemplates illegal activity. ${ }^{72}$ In interpreting Rule 68 this way, the court relied heavily on two state-court decisions that had reached the same conclusion: Centric-Jones Co $v$ Hufnagel ${ }^{73}$ and Hernandez $v$ United Supermarkets of Oklahoma, Inc. ${ }^{74}$

In Centric-Jones, the Colorado Supreme Court came to the same conclusion regarding Colorado's version of Rule 68 , but it provided a much more detailed justification. The essential facts closely paralleled Perkins, but this time, two defendants had extended a joint offer of judgment to the plaintiff, Centric-Jones Co. 75 When the trial court granted summary judgment for one of the two defendants based on the statute of limitations, both defendants immediately attempted to withdraw the offer and the plaintiff attempted to accept. ${ }^{76}$

First, the court affirmed the "well-established and persuasive" view that offers of judgment are irrevocable for the allotted statutory period. ${ }^{77}$ But this irrevocable nature does not come from contract principles, the court reasoned. Instead the court viewed an offer under Rule 68 as part of a "special statutory process" that should be enforced without "engrafting contract principles onto it." 78 The statute describes a mandatory proceeding that vests all discretion with the parties, not the courts. ${ }^{79}$ The court has no discretion to award costs to the prevailing party if the offer is refused and the subsequent trial judgment obtained is less favorable to the offeree than the offer, nor does it have discretion to alter or modify the judgment agreed upon by the parties. ${ }^{80}$

70 The older revision of Rule 68(a) used the word "shall." The general stylistic version of the Federal Rules changed this to "must" in the current version.

71 Perkins, 138 F3d at 338 (noting that entry of Rule 68 pursuant to notification of acceptance is mandatory).

72 Id at 338 n 5, citing Kasper v Board of Election Commissioners, 814 F2d 332, 338 (7th Cir 1987).

73848 P2d 942 (Colo 1993) (en banc).

74882 P2d 84 (Okla Civ App 1994).

75 Centric-Jones, 848 P2d at 945.

76 Id.

77 Id at 946 .

78 Id.

79 Centric-Jones, 848 P2d at 947.

80 Id. 
Next, the court reasoned that allowing acceptance after summary judgment would not conflict with the purpose of an offer of judgment. ${ }^{81}$ In the court's view, the risk of a summary judgment decision was apparent to both parties at the time the defendant extended the offer. The defendant enjoys total control over the inherent risks of an offer-unlike the plaintiff, who cannot refuse the offer without incurring a risk of cost shifting later. If the plaintiff risks having to pay costs if he recovers less than the offer, the defendant should have to risk losing an opportunity to lower its costs through summary judgment. ${ }^{82}$ Finally, the court reasoned that allowing summary judgment to affect the acceptance period for offers of judgment would remove the "definitiveness and predictability" needed to effectively promote settlement under the statute. ${ }^{83}$

While the majority in Centric-Jones disregarded contract principles, Justice William Erickson's concurrence adopted them to reach the same result. The irrevocable nature of the offer comes from its status as an option contract, he wrote, because the offeror receives valuable consideration in exchange for guaranteed power of acceptance for the statutory period. ${ }^{84}$ Like an option contract, the offer of judgment can be terminated under only certain circumstances-"lapse of time, death, or destruction of a person or thing essential for the performance of the proposed contract, or a supervening legal prohibition relating to the proposed contract." 85 The expiry of the option contract is set by statute, and summary judgment does not destroy the object of the contract-the pending lawsuit-because proceedings have not yet reached "final resolution." 86 Even after final judgment has been entered, an appeals court could still overturn the grant of summary judgment and return the case for a new trial. Thus, the defendant remained a party to the action and could still serve an offer of judgment at any time prior to the start of the trial. ${ }^{87}$ Finally, Justice Erickson distinguished summary judgment from final judgment, arguing that summary judgment does

81 Id at 948 .

82 Id at $947-48$.

83 Centric-Jones, $848 \mathrm{P} 2 \mathrm{~d}$ at 948.

84 Id at 948-49 n 1 (Erickson concurring), citing Morris K. Udall, May Offers of Judgment under Rule 68 Be Revoked before Acceptance?, 19 FRD 401, 403 (1957) (characterizing offers of judgments as "like an option that you have for ten days based upon a valuable consideration").

85 Centric-Jones, 848 P2d at 949 (Erickson concurring), citing Restatement (Second) of Contracts $\S 37$ (1981).

86 Centric-Jones, $848 \mathrm{P} 2 \mathrm{~d}$ at 949 (Erickson concurring).

87 Id at 949 n 3 (Erickson concurring). 
not truly dispose of an action unless the trial court expressly determines that there is no just reason for delay and directs entry of final judgment on the docket. ${ }^{88}$ Justice Erickson took this one step further by suggesting that the offer of judgment itself prevented the summary judgment order from becoming final. ${ }^{89}$

This contract-based approach was expressly adopted in Hernandez. The Oklahoma court of appeals adopted the reasoning of Justice Erickson's concurrence in Centric-Jones.90 The court treated the grant of summary judgment as interlocutory based on the existence of the outstanding offer, holding that the summary judgment ruling "remained open to modification, reconsideration or withdrawal" until the end of the acceptance pe$\operatorname{riod} .91$

\section{B. Courts Abrogating Rule 68 after Summary Judgment}

Justice Anthony Vollack's dissent in Centric-Jones argued for cutting off the plaintiff's power of acceptance after an intervening grant of summary judgment. ${ }^{22}$ Like the majority in Perkins, Justice Vollack used a plain-language approach, but he would have held that a plaintiff cannot accept an offer after losing summary judgment. According to Justice Vollack, the section of the Colorado equivalent of Rule 68 stating that "an offer not accepted shall be deemed withdrawn" and that an offer "made but not accepted does not preclude a subsequent offer" is consistent with common-law applications of the power of acceptance and revocation. ${ }^{93} \mathrm{He}$ rejected the idea that offers of judgment are irrevocable and should be treated as option contracts. Instead, Justice Vollack applied garden-variety contract principles that allow offerors to revoke unless the offeree has accepted. ${ }^{44}$ Thus, because both defendants had manifested intent to withdraw before Centric-Jones had accepted, the acceptance was invalid. ${ }^{95}$

\footnotetext{
88 Id at 950 (Erickson concurring).

89 Id at 949 (Erickson concurring) ("Any trial court ruling made during the period of time the offer is outstanding is effective and valid, subject only to a possibility that the ruling will be of no consequence if the offer of judgment is accepted.").

90 Hernandez, 882 P2d at 88-89. Oklahoma's offer-of-judgment statute used different language from Rule 68, but the Oklahoma court's decision to adopt the Erickson interpretation from Centric-Jones without engaging in substantial inquiry suggests that the court felt that the statutes operated similarly.

91 Id at 89, quoting Centric-Jones, 848 P2d at 950 (Erickson concurring).

92 Centric-Jones, $848 \mathrm{P} 2 \mathrm{~d}$ at 950 (Vollack dissenting).

93 Id at 955-56 (Vollack dissenting).

94 See Restatement (Second) of Contracts $\S 35(1)$ (1981).

95 Centric-Jones, 848 P2d at 957 (Vollack dissenting).
} 
Alternatively, Justice Vollack determined that the power of acceptance was conditioned on the "availability" of all parties to the offer. ${ }^{96}$ Unlike the majority, he viewed the grant of summary judgment as equivalent to dismissing a party from the lawsuit, making them unavailable for the purposes of the offer. ${ }^{97}$ Finally, Justice Vollack appealed to the "inherent power of district courts to resolve disputes,"98 suggesting that even if the language of the offer-of-judgment rule does not explicitly give a court the power to intervene, this power is assumed.

Justice Vollack failed to persuade a majority of justices on the Colorado Supreme Court, but the Eastern District of Tennessee in Day v Krystal Company99 picked up his torch. The Day court argued that plaintiffs should not be allowed to use an offer of judgment as an end run around summary judgment. More than other courts, it emphasized the value of finality after entry of final judgment. The court seized on the necessity of balancing "the need for finality with the need to render just decisions." 100

For support, the Day court also looked to the Arizona case, Wersch $v$ Radnor/Landgrant-A Phoenix Partnership, ${ }^{101}$ which concluded that a grant of summary judgment embracing the same issues contained in the offer of judgment effectively precluded a party's ability to accept that offer. ${ }^{102}$ The trial courts in Day and Wersch had entered orders of final judgment in the court dockets before the plaintiffs attempted to amend the judgment. ${ }^{103}$ The court in Wersch stretched finality a bit further than the federal standard by stating that "the summary judgment-even in unsigned minute-entry form-resolved all of the issues between the plaintiffs and this defendant" and thus could

96 Id at $957 \mathrm{n} 5$ (Vollack dissenting).

97 Id (Vollack dissenting).

98 Id at 957 n 6 (Vollack dissenting) ("The inherent powers which courts possess consist of all powers reasonably required to enable a court to efficiently perform its judicial functions."), citing Halaby, McCrea \& Cross v Hoffman, 831 P2d 902, 907 (Colo 1992).

99241 FRD 474 (ED Tenn 2007).

100 Id at 479 .

101961 P2d 1047 (Ariz App 1998).

102 Wersch, 961 P2d at 1050 (holding that "where summary judgment encompasses the same issues as those contained in the offer of judgment, summary judgment precludes a party's ability to accept a pending offer of judgment").

103 Day, 241 FRD at 475 ("Plaintiff accepted the offer of judgment after the Court had already entered a final judgment in favor of Defendant ...."); Wersch, 961 P2d at 1050 ("While a partial summary judgment may be changed prior to entry of final judgment, ... the judgment involved here was later certified as finally and formally entered."). 
be treated as a final judgment. ${ }^{104}$ Generally, federal courts do not accept minute orders as final judgments. ${ }^{105}$ To avoid this procedural wrinkle, Day distinguishes itself from Wersch by pointing to the fact that the Wersch court had granted summary judg. ment to only one of multiple parties in the case. It suggested that, despite the Wersch court's belief to the contrary, the decision was not final because "it did not resolve all claims in the action since there were other defendants in the action that were not privy to the summary judgment motion." 106 Nonetheless, Day still adopted the Wersch court's view of final judgment as the close of the case, rendering any further attempts to settle "futile."107 It also reasoned that, under "circumstances not contemplated by the rule," including an entry of final judgment, the mandatory nature of a Rule 68 offer yields to competing considerations. 108

For added support, Day also appealed to the policies behind summary judgment and the Federal Rules generally. Summary judgment, it noted, seeks to secure "just, speedy and inexpensive determination of every action." 109 The court reasoned that allowing Rule 68 to override summary judgments would frustrate its purpose. It also noted that allowing the plaintiff to nullify summary judgment had the effect of holding Rule 68 in "higher esteem" than FRCP $56 .{ }^{110}$ In the court's opinion, a better reading would give effect to both rules by allowing Rule 68 to operate up until the point summary judgment is rendered. ${ }^{111}$ Furthermore, no defendant would ever make a Rule 68 motion if it held the power to reverse a favorable summary judgment ruling. ${ }^{112} \mathrm{Al}-$ lowing acceptance would essentially punish that defendant for offering to settle the case, the court reasoned, working against the settlement-promoting purpose of Rule 68 and giving the

104 Wersch, 961 P2d at 1050.

105 See FRCP 58(a); ABF Capital Corp, a Delaware Corporation v Osley, 414 F3d 1061, 1064-65 (9th Cir 2005) (holding that a district court's minute order did not substi. tute for an entry of judgment in a separate document). But see Perry $v$ Sheet Metal Workers' Local No 73 Pension Fund, 585 F3d 358, 361-62 (7th Cir 2009) (suggesting that, although the court would not reach the argument, minute entries may satisfy the separate-document requirement in a future case).

106 Day, 241 FRD at $477 \mathrm{n} 2$.

107 Id at 478 .

108 Id. See also Colonial Penn Insurance Co, 887 F2d at 1240 ("[W]e believe that there are exceptional factual situations that may properly merit revocation of offers made pursuant to Rule 68.").

109 Day, 241 FRD at 478.

110 Id.

111 Id at 478-79.

112 Id. 
plaintiff-who normally could not have prevailed as a matter of law-a windfall. ${ }^{113}$

$$
\text { ** * }
$$

Taken as a whole, these cases demonstrate that both sides of this issue wield strong textual and policy support for their positions. Courts appear to have reached an impasse. Rather than focusing on the legal deadlock, this Comment reconsiders the way courts interpret Rule 68 in order to offer a more holistic solution.

\section{RECONCILING RULE 68 WITH SUMMARY JUDGMENTS}

This Part argues for a compromise of sorts by proposing that Rule 68 should be allowed to override court orders up until the entry of final judgment. First, it explores how courts might read Rule 68 to interpret the Rule, not as a contract, but as a stipulation. This Part argues that courts can interfere in the offeracceptance process in instances in which the court has the power to abrogate stipulations. Then, this proposal uses the different standards that govern amendment of summary and final judgments to justify the position that offers of judgment may control the outcome of a case up until entry of final judgment. Finally, this Part ends with several policy justifications for this interpretation of Rule 68 .

A. Reconsidering the Meaning of an "Offer to Allow Judgment"

The mechanics of offer-acceptance and entering judgment in Rule 68 have often been interpreted as the formation of an option contract that becomes a binding settlement contract upon acceptance. But a closer examination of the Rule's structure shows this conception is not necessary-or even particularly justified. The relevant section of Rule 68 states:

[A] party defending against a claim may serve on an opposing party an offer to allow judgment on specified terms, with the costs then accrued. If, within 14 days after being served, the opposing party serves written notice accepting the offer, either party may then file the offer and notice of acceptance, plus proof of service. The clerk must then enter judgment.114 
But what does an "offer to allow judgment" or "acceptance" of that offer mean within the context of Rule 68 ? The terms "offer" and "acceptance" have obvious contract connotations. Contract law defines acceptance as the manifestation of assent to an offer, ${ }^{115}$ which can give rise to a binding contract. Thus, many courts have-not unreasonably-analyzed Rule 68 under contract principles ${ }^{116}$ and have conceptualized acceptance as forming a binding settlement contract. ${ }^{117}$ However, Rule 68 conspicuously omits any reference to the formation of a contract, and the Supreme Court has never used contract principles to interpret it. In fact, some courts explicitly or implicitly decline to characterize the Rule in contractual terms. ${ }^{118} \mathrm{~A}$ few courts interpreting an offer's terms have also sensed a difference between Rule 68 and a "simple contract." 119 These courts have not articulated a strong rationale for treating offers of judgment as separate from contracts, ${ }^{120}$ but the logic behind their instinct becomes clearer upon further examination.

1. Comparing Rule 68 to contracts and stipulations.

While they look similar at first, the limited scope and consequences of a Rule 68 agreement distinguish it from a typical settlement contract. First, a contract's flexibility and the breadth of its potential terms make it significantly more versatile than an agreement reached through Rule 68. For example, parties using a settlement contract can simply dismiss a case without entering formal judgment or admitting liability. In contrast, litigants cannot rely on courts to uphold disclaimers of liability in a Rule

115 See Restatement (Second) of Contracts $\S 50(1)$ (1981).

116 See, for example, Whitaker $v$ Associated Credit Services, Inc, 946 F2d 1222, 1226 (6th Cir 1991). See also Wright, Miller, and Marcus, 12 Federal Practice and Procedure $\S 3002$ at 94 (cited in note 58) ("As a general matter, it is agreed that since Rule 68 offers are basically offers of settlement their provisions should be interpreted according to contract law principles.").

117 See, for example, Mallory, 922 F2d at 1279 ("[A] Rule 68 judgment results from a binding contract."); Whitaker, 946 F2d at 1226 (disregarding an offer of judgment because the offer and acceptance did not result in "an enforceable contract").

118 See, for example, Centric-Jones, $848 \mathrm{P} 2 \mathrm{~d}$ at 946 (refusing to engraft contract principles onto Rule 68's operation and characterizing the Rule as a "special statutory process"); Perkins, 138 F3d at 336 (analyzing Rule 68 without comparing it to a contract).

119 Shorter v Valley Bank \& Trust Co, 678 F Supp 714, 720 (ND Ill 1988) ("[T]he arrangement here is not a simple contract; it involves an accepted offer of judgment, and there is a difference."). See also Webb v James, 147 F3d 617, 621 (7th Cir 1998) ("Rule 68 'contracts' should therefore be treated differently than ordinary contracts.").

120 See Centric-Jones, 848 P2d at 946 (characterizing Rule 68's operation as a "special statutory process," rather than the operation of contract rules); Perkins, 138 F3d at 336 (offering no explanation for the court's avoidance of contract comparisons). 
68 agreement. ${ }^{121}$ And courts do not allow conditions that require confidentiality. ${ }^{122}$ Second, settlement contracts allow parties to create their own enforcement mechanisms and terms of default. But Rule 68 necessarily involves judicial mechanisms, and proper acceptance necessarily ends in entry of judgment. ${ }^{123}$ Third, Rule 68 agreements can arise only prior to trial. Settlement contracts, however, can be made at any time during the case, including after trial if the parties are unhappy with the result. Finally, if Rule 68's drafters intended the Rule to incorporate contract principles, they could have saved time by simply using the term "option contract." Instead, the Rule specifies the peculiar action of "offer[ing] to allow judgment on specified terms."124 Thus, Rule 68 does not explicitly invoke contract principles and fits awkwardly into our conceptions of how settlement contracts operate.

A better fit emerges by looking to contract's narrower cousin, the stipulation. A stipulation is any "promise or agreement with reference to a pending judicial proceeding, made by a party to the proceeding or his attorney, [that] is binding without consideration." 125 Stipulations closely resemble contracts, but the agreement they contain is limited to "a pending judicial proceeding." 126 Stipulations also follow slightly different rules from contracts. ${ }^{127}$ Proper stipulations still become enforceable on the parties within a judicial proceeding, ${ }^{128}$ but "a court has the inherent power to avoid a stipulation in law or equity." 129 For example, stipulations materially affecting aspects of litigation procedure sometimes require court approval, ${ }^{130}$ and some courts have held

121 See Shelton, 91 Minn L Rev at 881-83 (cited in note 12).

122 See Wright, Miller, and Marcus, 12 Federal Practice and Procedure $\S 3002$ at 18 (2013 Supp) (cited in note 58) ("[A]n offer that requires a confidential settlement rather than a court judgment seeks something not authorized by the rule."), citing McCauley $v$ Trans Union, LLC, 402 F3d 340 (2d Cir 2005).

123 See FRCP 68(a).

124 FRCP 68(a).

125 Restatement (Second) of Contracts § 94 (1981).

126 Id. See also 73 Am Jur 2d Stipulations $\$ 1$ at 529 (2012) (defining stipulation as an "agreement, admission, or concession made in a judicial proceeding by the parties or their attorneys, respecting some matter or incident thereto").

127 See Southern Colonization Co v Circuit Court of St Croix County, 203 NW 923, 925 (Wis 1925).

128 See 73 Am Jur 2d Stipulations $§ 7$ at 538 (2012).

129 Id $\S 12$ at 544. See also Osborne v United States, 351 F2d 111, 120 (8th Cir 1965) ("[R]elief may be granted from a stipulation under appropriate circumstances.").

130 See 73 Am Jur 2d Stipulations $§ 7$ at 539 (2012). 
that purely procedural stipulations cannot bind the court.131 Contradictory or confusing stipulations may also be disregarded. ${ }^{132}$ Moreover, the Federal Rules allow courts to outright veto certain stipulations. For example, FRCP 29 empowers parties to stipulate to procedures of discovery "[u]nless the court orders otherwise." 133

Rule 68 agreements fit all the criteria for a stipulation. This becomes most apparent when we look separately at the two stages of a Rule 68 agreement: (1) the initial offer-acceptance transaction and (2) the ultimate judgment embodying the agreement's terms. When parties reach an agreement under the first half of Rule 68(a), that agreement allows the parties only to enter judgment against the defendant-a result limited to the judicial proceeding at hand. No other rights or obligations arise. In fact, the agreement does not appear to bind the parties at this stage. The Rule gives parties discretion regarding whether to actually enter judgment by providing that they "may" file their agreement with the court. ${ }^{134}$ Only upon filing does the agreement give rise to a judgment that binds the parties. In a nutshell, the initial agreement amounts to a procedural stipulation to "allow judgment." Only at stage two-the entry of judgmentdo the substantive terms of the agreement become binding.

Viewing Rule 68 as a stipulation comports with Supreme Court precedent on the subject. In Marek, the Supreme Court observed that "the drafters' concern [in Rule 68] was not so much with the particular components of offers, but with the judgments to be allowed against defendants." ${ }^{135}$ In other words, the Court viewed the primary function of an agreement reached under Rule 68 as a procedural event: the allowance of a judgment. This parallels the way stipulations generally contemplate procedural elements in a judicial proceeding-such as agreements to certain background facts that allow litigants to move toward the case's actual adjudication-rather than substantive

131 See, for example, TIF Instruments, Inc v Colette, 713 F2d 197, 201 (6th Cir 1983); Wechsler $v$ Zen, 140 NW2d 581, 583 (Mich App 1966).

132 See 73 Am Jur 2d Stipulations $§ 7$ at 539-40 (2012).

133 FRCP 29.

134 FRCP 68(a). Rule 68 does not give a clear time limit on how long the parties can wait before filing their agreement. However, courts could easily interpret FRCP 68(a)'s reference to "within 14 days after being served" as also applying to filing.

135 Marek, 473 US at 6. 
or extrinsic ones-such as a contractual agreement that creates or controls the scope of rights and remedies. ${ }^{136}$

A Supreme Court concurring opinion also adopted the word "stipulate" to describe Rule 68. In a concurrence to Delta Air Lines, Inc v August, ${ }^{137}$ Justice Lewis Powell characterized Rule 68 as "a proposal of settlement that, by definition, stipulates that the plaintiff shall be treated as the prevailing party." 138 The Court's majority later adopted this conception in Marek by allowing plaintiffs who had accepted Rule 68 offers to prevail for purposes of fee-shifting statutes. ${ }^{139}$

The Court's treatment of judgments reached through Rule 68 in Delta Air Lines and Marek also implicitly supports treating the Rule as a stipulation. Had the parties in either case simply settled their dispute through contract, there would be no discussion of prevailing parties because that issue would have been moot. In a settlement contract, money changes hands regardless of which party "prevailed," and the fee-shifting statute does not control. ${ }^{140}$ Instead of taking this view, the Court treated a judgment reached through Rule 68 the same as a judgment reached through trial, which necessarily triggers a fee-shifting statute. Accordingly, Rule 68 allows parties to stipulate away the need for trial, but the agreement has no effect on the extrinsic right to attorney's fees after a favorable judgment.

Other features of a Rule 68 agreement also resemble a stipulation. The purpose of a stipulation is thought to be "the avoidance of delay, trouble, [ ] expense,"141 and to "reduce the volume of litigation," 142 which parallels Rule 68's purpose of promoting settlement. Additionally, Rule 68's insistence on "written notice" 143 matches the common requirement that stipulations made outside court be evidenced in writing. ${ }^{144}$ Oral contracts, on the other hand, can be binding even when made outside of court. ${ }^{145}$

136 For an important example of the distinction between procedure and substance, see the Rules Enabling Act, Pub L No 73-415, 48 Stat 1064 (1934), codified as amended at 28 USC $\$ 2072$ (allowing the Supreme Court to prescribe general rules of "practice and procedure"-including the FRCP and Rule 68 in particular-but prohibiting rules that "abridge, enlarge or modify any substantive right").

137450 US 346 (1981).

138 Id at 363 (Powell concurring) (emphasis added).

139 See Marek, 473 US at 11 . See also 42 USC $\S 1988(\mathrm{~b})$.

140 Of course, the parties will presumably take the fee-shifting statute into account during negotiations over the settlement amount, but they are not bound by it.

14173 Am Jur 2d Stipulations $\S 1$ at 529-30 (2012).

142 See Restatement (Second) of Contracts $\$ 94$, comment a (1981).

143 FRCP 68(a).

144 See Restatement (Second) of Contracts $§ 94(a)$ (1981).

145 See, for example, United States $v$ White, 675 F3d 1073, 1079 (8th Cir 2012). 
Moreover, other Federal Rules use agreements they characterize as "stipulations" to trigger cost-shifting provisions similar to Rule 68. Consider FRCP 36 and FRCP 37(c)(2). Rule 36 allows parties to ask their opponents to admit to certain facts, applications of law to facts, or the genuineness of documents. ${ }^{146}$ This saves litigants the time of having to prove each fact or application of law. These admissions are conclusively binding only for purposes of the pending action-a third party cannot rely on the admission in another proceeding and admissions cannot be used for any other purpose. Accordingly, the Advisory Committee Notes to Rule 36 describe an agreement under the Rule as a stipulation, noting that "in form and substance a Rule 36 admission is comparable to ... a stipulation." ${ }^{147}$

If the opponent fails to stipulate to the items requested and the requesting party later proves a fact to be true or a document to be genuine, the requesting party can move for the opponent to pay the "reasonable expenses, including attorney's fees, incurred in making that proof." 148 This gives parties an extra incentive to stipulate to certain facts because failure to do so results in cost shifting-just like failure to accept an agreement under Rule 68 can result in cost shifting.

Taken together, stipulation under Rule 36 and cost shifting under Rule 37(c)(2) closely parallel an agreement under Rule 68(a) and cost shifting under Rule 68(d). Rule 36 requests an agreement on certain facts; Rule 68(a) requests an agreement on the outcome of a proceeding. Rule 36 agreements bind only parties to the action and have no other use; Rule 68 agreements bind only parties to the action and have no other use. Rule 37(c) triggers cost shifting for "failure to admit"; Rule 68(d) triggers cost shifting for failure to accept. Because the Federal Rules treat an agreement under Rule 36 as a stipulation, it seems natural to treat Rule 68 similarly.

Ultimately, the similarities between Rule 68 and stipulations suggest that Rule 68 agreements should be viewed as stipulations to the entry and terms of judgment, rather than fully realized settlement contracts-a critical difference in light of the power courts wield to set aside or prevent stipulations that alter court procedure.

146 See FRCP 36(a).

147 See FRCP 36, Advisory Committee Notes to the 1970 Amendments.

148 FRCP 37(c)(2). 
2. Distinguishing revocation of a contract from nullification of a stipulation.

Even if Rule 68 amounts to a stipulation, courts may conclude that the irrevocability doctrine and the Rule's mandatory language strip the court of any discretion to prevent entry of judgment after the plaintiff accepts. But this view overstates the mandatory nature of Rule 68. It conflates a party's attempt to revoke an offer-which the irrevocability doctrine prohibitswith a court's power to make procedural decisions that prevent stipulation-to which the irrevocability doctrine does not apply.

In their discussion of the irrevocability doctrine, courts allowing Rule 68 to override their own judgments have blurred the line between revocation by the parties and nullification by the court. For example, the Perkins court adopted broad language to find that neither the parties nor the court can abridge a plaintiff's power of acceptance. ${ }^{149}$ But the doctrine of irrevocability constrains the defendant, not the court. Irrevocability cases like Richardson, Erdman, and Fisher dealt with attempts by the defendant to revoke an offer after realizing some mistake has been made in its wording or calculation of the settlement amount.150 They did not address the court's power to nullify acceptance.

Ultimately, courts construing Rule 68 offers as stipulations need not view the Rule with such reverence. As discussed above, courts enjoy much more discretion when deciding whether to give binding effect to a stipulation. There is no need to defer on contractual grounds. And the doctrine of irrevocability does not constrain the power of the court to nullify a stipulation with an appropriate procedural event, as the courts in Perkins and Centric-Jones seem to assume. ${ }^{151}$ The next Section will argue that final judgment is exactly the kind of procedural event to fill this role.

149 See Perkins, 138 F3d at 338 (holding that the plain language of Rule 68 mandates that the offer remain valid and open for acceptance for the full ten-day period); Centric-Jones, 848 P2d at 946 (affirming the "well-established and persuasive" view that offers of judgment are irrevocable for the allotted statutory period and not subject to the discretion of the court). See also Mallory, 922 F2d at 1279 ("Rule 68 also leaves no discretion in the district court to do anything but enter judgment once an offer has been accepted.").

150 See Richardson, 49 F3d at 762; Erdman, 926 F2d at 879; Fisher, 110 FRD at 76.

151 See Perkins, 138 F3d at 338; Centric-Jones, 848 P2d at 946. 


\section{B. Crossing the Rubicon: How the Standard for Amending Judgments Impacts Rule 68}

The ambiguities of Rule 68 may seem confusing enough, but its intersection with the law of judgments raises another critical question: what does summary judgment mean? From the standpoint of preventing a stipulation, the short answer is that summary judgment generally has much less procedural importance when unresolved claims or issues remain. However, granting full summary judgment leads to disposal of the case through entry of final judgment, which has a much stronger procedural impact on stipulations. This Section distinguishes summary judgment from final judgment and then surveys situations in which a final judgment can be amended or altered. Finally, it argues that the law of judgments prevents parties from stipulating to the amendment of a final judgment under Rule 68. In other words, courts will not enforce a Rule 68 agreement after final judgment has been entered.

1. Distinguishing summary judgment from final judgment.

Summary judgment and final judgment can relate closely to each other, but they differ significantly in substance. The FRCP prescribe criteria governing what court memorandums may qualify as a grant of summary judgment or final judgment. However, in the most basic sense, both are court orders that the court clerk will enter into a case docket separately.

FRCP 56 governs summary judgment. The Rule allows a party to move for full or partial dismissal of a case if the movant can prove that (1) there is "no genuine dispute as to any material fact," and (2) the party is therefore entitled to judgment as a matter of law. ${ }^{152}$ The ability to dispose of a case without proceeding to trial promotes a "just, speedy, and inexpensive determination of every action." 153

Traditionally, the prerequisites and purposes of summary judgment have received far more attention than its procedural role. Summary judgment comes in two flavors-partial and full. Partial summary judgment affects the ability of litigants to continue to pursue or revisit a particular issue, ${ }^{154}$ but the broader

152 FRCP 56(a).

153 FRCP 1. See also Warren Freedman, Summary Judgment and Other Preclusive Devices 1 (Quorum 1989) (discussing the purpose of summary judgment in the Federal Rules and its role in "obviat[ing] the need for a trial where no fact issues exist").

154 See Charles Alan Wright, Arthur R. Miller, and Mary Kay Kane, 10A Federal Practice and Procedure $\S 2712$ at 212-13 (West 3d ed 1998). 
case usually continues on other elements or causes of action. Full summary judgment will dispose of the entire case. ${ }^{155}$ However, granting the motion itself does not procedurally dispose of the case; it merely enables the entry of a separate judgment on the court docket pursuant to FRCP 79(b) that disposes of the case. ${ }^{156}$ It is that separate judgment-the final judgment-that effectuates disposal.157

FRCP 58 governs entry of final judgment. It requires that a final judgment be set out in a separate document from any other opinion or memorandum, 158 and it distinguishes procedural events that mandate entry of final judgment without court approval from procedural events that require court approval prior to entry of final judgment.159 The court clerk "must" enter final judgment, unless ordered otherwise by the court, when (1) the jury returns a general verdict, (2) the court awards only costs or a sum certain, or (3) the court denies all relief.160 Final judgments require court approval when the jury returns a special verdict or the court grants any other form of relief. ${ }^{161}$ Accordingly, a grant of full summary judgment denying all relief requires immediate entry of final judgment, unless the court says otherwise. The timing of entry occurs when the separate document is entered into the court docket or when 150 days have run from entry of an unseparated judgment. ${ }^{162}$

In addition to the separate-document requirement, purported final judgments must meet two other criteria. First, some courts have held that judgments including extraneous text, such as an explanation of the court's rationale, will fail to meet the separate-document requirement. ${ }^{163}$ This further prevents orders granting summary judgment from also serving as a final judgment.

155 See FRCP 56, Advisory Committee Notes to the 1937 Adoption ("Summary judgment procedure is a method for promptly disposing of actions in which there is no genuine issue as to any material fact.").

156 FRCP 58(c).

157 See FRCP 58(c) (providing that the timing of entry of final judgment does not occur until the separate judgment is entered in the civil docket under Rule 79(a)).

158 See FRCP 58(a).

159 FRCP 58(b).

160 FRCP 58(b)(1).

161 FRCP 58(b)(2).

162 FRCP 58(c).

163 See, for example, In re Cendant Corp Securities Litigation, 454 F3d 235, 243 (3d Cir 2006) (holding that a lengthy description of facts and procedural history precludes an order from complying with the separate-document rule); Otis $v$ City of Chicago, 29 F3d 1159,1163 (7th Cir 1994) (holding that a Rule 58 judgment "should be a self-contained document, saying who has won and what relief has been awarded, but omitting the reasons for this disposition, which should appear in the court's opinion"). 
Second, a final judgment must specify the relief awarded to the prevailing party if the order concludes relief is warranted. ${ }^{164}$ However, if an order disposes of the plaintiff's case entirely-as full summary judgment would-the final judgment need not specify relief. ${ }^{165}$ In these instances, the disposition of a case is "easy to infer," and the judgment need not state it explicitly. ${ }^{166}$

A final judgment leaves nothing left to do in the case except to enforce its terms. ${ }^{167}$ All issues of law or fact essential to the case have been determined, and, if the court has decided to award relief, the amount of the damages or the form or scope of other relief has been defined. ${ }^{168}$ In short, the case has ended in the trial court. But final judgments have importance even beyond the trial court. Cases addressing the distinction between nonfinal and final judgments tend to do so in the context of appellate review, ${ }^{169}$ and the Supreme Court has held that a "judgment" for the purposes of the Federal Rules is equivalent to a "final decision" required by statute before appeals courts gain jurisdiction. ${ }^{170}$ Thus, while summary judgment and final judgment may seem similar at first, the nature and effect of each differ dramatically.

164 See American Interinsurance Exchange $v$ Occidental Fire and Casualty Co of North Carolina, 835 F2d 157, 159-60 (7th Cir 1987) (holding that failure to include the declaratory relief that parties had sued to receive robbed the judgment of finality at the trial level).

165 See Rush University Medical Center v Leavitt, 535 F3d 735, 737 (7th Cir 2008) ("Unless the plaintiff loses outright, a judgment must provide the relief to which the winner is entitled.").

166 Id ("Sometimes it is easy to infer the disposition, and then the appeal may proceed despite technical shortcomings.").

167 See Catlin v United States, 324 US 229, 233 (1945) ("A 'final decision' generally is one which ends the litigation on the merits and leaves nothing for the court to do but execute the judgment.").

168 See Restatement (Second) of Judgments § 13, comment b (1982):

Finality will be lacking if an issue of law or fact essential to the adjudication of the claim has been reserved for future determination, or if the court has decided that the plaintiff should have relief against the defendant of the claim but the amount of the damages, or the form or scope of other relief, remains to be determined.

169 See, for example, American Interinsurance Exchange, 835 F2d at 160 (declining to exercise appellate jurisdiction due to a lack of finality in the "judgment" entered by a district court).

170 See Bankers Trust Co $v$ Mallis, 435 US 381, 384 n 4 (1978) ('A 'judgment' for purposes of the Federal Rules of Civil Procedure would appear to be equivalent to a 'final decision' as that term is used in 28 U.S.C. $\S 1291 . ")$. 
2. Altering, amending, and reconsidering judgments.

Judgments are not the be-all and end-all of civil procedure. Even after entry of judgment, parties can try to convince a court that it should reconsider. But the standards that govern reconsideration of a judgment depend at least in part on the kind of judgment in question. Although some judgments can be amended easily, courts rarely reconsider final judgments.

FRCP 59(e) allows courts to alter or amend judgments if a motion is filed within twenty-eight days after the entry of judgment. ${ }^{171}$ The Rule covers any motion seeking a substantive alteration of the judgment, ${ }^{172}$ including motions to reconsider ${ }^{173}$ and motions to vacate a judgment. ${ }^{174}$ Rule 59(e) does not specify criteria, but case law has established four grounds for amending a judgment: (1) to incorporate an intervening change in the law, (2) to reflect new evidence not available at the time of the trial, (3) to correct a clear legal error, or (4) to prevent a manifest injustice. ${ }^{175}$ Instances under the manifest-injustice ground include exceptional circumstances like misconduct of counsel.176 Rule 59(e) motions should not be granted when the grant will "serve no useful purpose" 177 or when the motion attempts to relitigate old matters, raise old arguments, or present evidence that could have been presented prior to entry of judgment. 178

Critically, the standard of discretion for altering judgments depends on the case's procedural posture. District courts have considerable discretion when considering a Rule 59(e) motion to alter an "interlocutory" judgment-one that does not bring the

171 FRCP 59(e) ("A motion to alter or amend a judgment must be filed no later than 28 days after the entry of the judgment.").

172 See Hannon v Maschner, 981 F2d 1142, 1144 n 2 (10th Cir 1992) ("Where ... the motion requests a substantive change in the district court's decision, it may be considered under Rule 59(e).").

173 See Cockrel v Shelby County School District, 270 F3d 1036, 1047 (6th Cir 2001) ("Motions for reconsideration ... are generally treated as a motion to alter or amend the judgment pursuant to Fed.R.Civ.P. 59(e).").

174 See Foman v Davis, 371 US 178, 181 (1962) (approving of the appellate court's treatment of a motion to vacate judgment under Rule 59(e)); Sonnenblick-Goldman Corp $v$ Nowalk, 420 F2d 858, 859 (3d Cir 1970) (holding that a motion to vacate judgment was a motion to alter or amend judgment under Rule 59(e)).

175 See Jacobs v Electronic Data Systems Corp, 240 FRD 595, 599 (MD Ala 2007).

176 See id at 600 .

177 Id at 599, citing Charles Alan Wright, Arthur R. Miller, and Mary Kay Kane, 11 Federal Practice and Procedure $\S 2810.1$ at 124-27 (West 2d ed 1995).

178 See Charles Alan Wright, Arthur R. Miller, and Mary Kay Kane, 11 Federal Practice and Procedure $\S 2810.1$ at 163-64 (West 3d ed 2012). 
case to a final resolution.179 However, reconsideration of final judgment is an "extraordinary remedy that should be used sparingly." 180 This added scrutiny helps courts avoid backtracking through judgments that depend on complicated and interrelated questions. ${ }^{181}$

Parties who seek reconsideration of a judgment more than ten days after the entry of judgment must move for relief under Rule 60(b). ${ }^{182}$ These motions may be granted under only the explicit, limited circumstances of

(1) mistake, inadvertence, surprise, or excusable neglect;

(2) newly discovered evidence that, with reasonable diligence, could not have been discovered in time to move for a new trial under Rule 59(b);

(3) fraud (whether previously called intrinsic or extrinsic), misrepresentation, or misconduct by an opposing party;

(4) the judgment is void;

(5) the judgment has been satisfied, released, or discharged; it is based on an earlier judgment that has been reversed or vacated; or applying it prospectively is no longer equitable; or

(6) any other reason that justifies relief. ${ }^{183}$

Subsection (6)'s catch-all category is reserved for "extraordinary circumstances," 184 such as misconduct by a witness. ${ }^{185}$

179 Holland v Valley Services, Inc, 845 F Supp 2d 220, 222 (DDC 2012) ("A district court may revise its own interlocutory decisions at any time before the entry of a judg. ment adjudicating all the claims and all the parties' rights and liabilities.") (citations and quotation marks omitted). See also Templet v HydroChem Inc, 367 F3d 473, 479 (5th Cir 2004) (noting that courts enjoy "considerable discretion" when deciding whether to reopen a case in response to a motion for reconsideration but that "such discretion is not limitless").

180 Templet, 367 F3d at 479, citing Clancy $v$ Employers Health Insurance Co, $101 \mathrm{~F}$ Supp 2d 463, 465 (ED La 2000).

181 See Sussman v Salem, Saxon \& Nielsen, PA, 153 FRD 689, 694 (MD Fla 1994) (stating the need to avoid "backtrack[ing] through the paths of litigation which are often laced with close questions").

182 See Tracy Bateman Farrell, et al, 27A Federal Procedure, Lawyers Edition $\S 62: 691$ (West 2012).

183 FRCP 60(b).

184 Gonzalez $v$ Crosby, 545 US 524, 535 (2005) ("[O]ur cases have required a movant seeking relief under Rule 60(b)(6) to show 'extraordinary circumstances' justifying the reopening of a final judgment."), quoting Ackermann v United States, 340 US 193, 199 (1950).

185 See Richardson, 49 F3d at 765-66. 
3. The stricter standard for amending final judgments prevents stipulation under Rule 68.

Here is where the pieces come together. Acceptance of a Rule 68 offer effectively stipulates to the entry of judgment, or as the case may be, the modification of any judgment previously entered. But agreement among the parties to allow entry of judgment does not necessarily bind the court. As the previous Section explained, judgments are subject to special mechanisms of amendment and modification. If a judgment has been entered, Rule 68 cannot mandate the entry of another judgment unless the parties also move to amend the existing judgment under Rule $59(\mathrm{e})$ or $60(\mathrm{~b}) .^{186}$

But as explained above, the standard for amending a judgment depends on that nature of that judgment. Final judgments can be modified only "rarely" and in "extraordinary" circumstances under Rule 59(e). ${ }^{187}$ And none of Rule 60(b)'s subsections requires granting relief from a judgment upon stipulation by the parties. ${ }^{188}$ Even $60(\mathrm{~b})(6)$ 's "any other reason" provision requires a showing of "extraordinary circumstances," and mere stipulations are unlikely to meet this standard. ${ }^{189}$ Thus, acceptance of an offer of judgment may warrant amending some judgments, but not a final judgment.

Accordingly, if either party can file the offer, notice of acceptance, proof of service, and a motion to amend judgment before the court clerk enters final judgment, that party will have a procedural method to enforce the stipulation. But if the court enters final judgment before the parties file, their stipulation cannot overcome that judgment except under extraordinary circumstances.

In practice, however, this distinction will probably matter much less to litigants. This is because most courts grant full summary judgment and enter final judgment simultaneously, making the two functionally equivalent. ${ }^{190}$ In fact, the courts in Perkins and Day entered final judgment on the same day that

186 Plaintiffs seeking to accept an offer of judgment after the court has ruled on summary judgment submit motions to amend the judgment under Rule 59(e) simultaneously with their proof of acceptance and service on the defendant. See, for example, Perkins, 138 F3d at 338 .

187 See note 180 and accompanying text.

188 See note 183 and accompanying text.

189 See note 184 and accompanying text.

190 See FRCP 58(b) (requiring the court clerk to enter final judgment "promptly" after disposal of a case unless the court orders otherwise). 
they granted a full summary judgment. ${ }^{191}$ Thus, from the perspective of the litigants in those cases, the distinction between full summary judgments and final judgments is one without a difference. The parties cannot stipulate to entry of judgment. Formal distinctions explaining why will not afford the parties much benefit, and litigants will actually need to note only the difference between partial and full summary judgment.

But this will not always be the case. For example, a court might enter partial summary judgment that overlaps with an offer of judgment's terms but does not completely resolve the case. Or, a court could enter full summary judgment but order the clerk to postpone entry of final judgment. This might occur, for example, if the court has answered the legal questions before it but must make damage calculations that require further submissions by the parties. In this example, no procedural event prevents the parties from using Rule 68 to bring the case to a quick close.

Moreover, final judgment provides a uniquely logical place to abrogate Rule 68 because it differs in kind from other court orders or intervening incidents. Any number of events will alter the way both parties value settlement in a case. For example, the death of a witness or pretrial exclusion of evidence may significantly impact one party's chances of prevailing. Yet, Rule 68 makes no provision for these events, and it is unclear how courts might draw a line between events that should abrogate the Rule and events that shouldn't.

Some courts have expressed fear of a slippery slope: abrogating Rule 68 through judgment will pave the way for other court orders to have a similar effect, they say, eroding the certainty that animates the Rule. ${ }^{192}$ In their view, the plaintiff must have fourteen days to accept, and all other intervening events must be treated consistently. Thus, some courts have interpreted the risk of intervening material events as part of the bargain a defendant accepts when making the offer.

Final judgment solves this slippery slope problem because it differs significantly from other court orders and provides a bright-line rule that allows courts to continue treating all other material events consistently. Once final judgment is entered, the defendant has gained more than an increased chance of prevailing.

191 See Judgment Order, Day v Krystal Co, No 1:05-CV-00300 (ED Tenn filed Jan 24, 2007); Docket No 97-2959, Perkins v US West Communications, No 97-2959 (8th Cir filed July 21, 1997).

192 See, for example, Centric-Jones, 848 P2d at 948. 
He has prevailed. Rather than simply overpaying for a resolution to the case, the defendant has lost all reason for paying at all because litigation has ended. No further judicial economy can be gained by entering a judgment in favor of the plaintiff, and any further amendments or alterations become "futile" according to Rule 68's settlement-promotion purpose. ${ }^{193}$ This distinction makes final judgment fundamentally different from all other intervening events, which alter only the chance that a party will prevail and leave open the possibility of further litigation costs.

$$
\text { * * * }
$$

The stipulation approach charts a compromise between advocates on both sides of the Rule 68 split. By operating in cases that involve a grant of summary judgment but the potential for continuing litigation, the approach honors the policy instincts of courts like Perkins and the settlement-promoting purpose of Rule 68. And by ceasing to operate in cases that have truly reached final resolution, it respects the concerns of futility and finality expressed in Day.

\section{Beyond Procedure: How the Stipulation Approach Improves Rule 68's Operation}

In addition to resolving the split between courts, the stipulation approach improves Rule 68's operation in three important ways: (1) it clarifies and simplifies ex ante settlement predictions, (2) it incentivizes sharing information in ways that promotes judicial efficiency, and (3) it does not rely on parties to contract around the solution. This Section elaborates on each improvement in turn.

1. Clarifies and simplifies ex ante settlement predictions.

In his examination of the Rule's incentives, Professor Geoffrey Miller laid out a systematic formula for how defendants approach Rule 68 ex ante. ${ }^{194}$ In its simplest expression, the amount a defendant offers to settle will depend on the amount of liability in question, discounted by his estimated chances at trial, plus the expenses of taking the claim to trial. ${ }^{195}$ Using this formula,

193 Day, 241 FRD at 478.

194 Geoffrey P. Miller, An Economic Analysis of Rule 68, $15 \mathrm{~J}$ Legal Stud 93, 104 (1986).

195 Id. 
Professor Miller described how expenses and discounts affect Rule 68's effectiveness. ${ }^{196}$

The same analytical method can be applied to a pending summary judgment motion. Summary judgment acts as a lowadditional-cost way to resolve the case. Comparatively few additional costs mean the defendant will not raise his settlement amount-a pretrial settlement will save roughly the same amount whether it occurs before or after summary judgment. However, the defendant will discount his offer further if he believes he has a better chance of prevailing at summary judgment than at trial. ${ }^{197}$ For example, the defendant might anticipate that an unlikeable witness will make trial more of a gamble, and therefore believe summary judgment is his best bet. So, at the point of summary judgment, defendants calculate their offer using Professor Miller's formula plus an additional discount based on their perceived chances at summary judgment.

Now imagine the defendant knows ahead of time that the court will allow the plaintiff to accept his offer even if summary judgment is first granted in his favor. The defendant appreciates that a rational plaintiff will accept in this situation because suddenly the alternative is defeat. Thus, the defendant will want to modify his previous discount based on the chance that summary judgment will be granted too soon, allowing the plaintiff to grasp victory from him. But how should he calculate this discount? Assuming the defendant does not know when the court will rule, he cannot rationally discount his offer ex ante. As noted in Part I, practitioners point to uncertainty as a cause for Rule 68's underuse. So defendants who cannot rationally discount are less likely to use Rule 68 at all.

To avoid this uncertainty, the defendant could try varying the timing of an offer. For example, the defendant could wait to extend an offer of judgment until after a ruling on the motion for summary judgment. But summary judgment motions routinely take months to decide, and waiting for a court ruling contradicts the quick resolution that Rule 68 is intended to produce. Waiting may also foreclose the defendant's ability to use Rule 68 altogether if the start of trial grows near. Reversing this strategy fails to do much better. Defendants who extend an offer of judgment first and wait until the end of the acceptance period before

196 Id.

197 If the defendant believes his chances are about the same at summary judgment or trial, there is no need to discount. However, the uncertainties of trial--especially a jury trial-typically make summary judgment more attractive. 
moving for summary judgment inherently make the initial offer with less knowledge of their case and their opponent's. ${ }^{198}$ Rule 68 requires both litigants to think hard about their chances at trial, and it naturally becomes much more difficult to evaluate success at a much earlier point in litigation. Again, uncertainty will prevent use. Moreover, requiring careful timing of the offer makes Rule 68 offers even less flexible and further inhibits their potential for settlement promotion.

Allowing final judgment to nullify Rule 68 solves this problem by making the ex ante calculation easier and avoiding the need to properly time motions. A defendant who knows that the court will not allow acceptance after entry of final judgment can simply discount his offer as usual. A favorable ruling of full summary judgment means the offer becomes invalid, negating the need to discount. An unfavorable ruling or a partialsummary judgment ruling will allow the parties to continue litigation, and the defendant can simply make another offer calibrated to his chances and expenses going forward. Finally, the defendant need not vary the timing of his offer because neither outcome of summary judgment conflicts with the purpose of his offer. A favorable ruling ends litigation-the exact situation he sought. An unfavorable ruling simply renders his offer too lowa trivial difficulty that can be remedied by extending an updated offer. Thus, a clear default rule preventing acceptance after entry of final judgment promotes the definiteness and predictability needed to induce defendants to extend offers in the first place.

2. Incentivizes information sharing in ways that promote judicial efficiency.

Under the current interpretation of Rule 68 , both plaintiffs and defendants have an incentive to keep courts in the dark. Plaintiffs will not inform the court of a pending Rule 68 offer because they may be able to use such an offer to overturn an unfavorable summary judgment ruling later. Defendants will not inform the court because, while the defendant is willing to accept settlement, he will still prefer resolution by summary judgment. Thus, defendants will avoid informing the court of any reason to postpone ruling on summary judgment.

198 See Miller, $15 \mathrm{~J}$ Legal Stud at 95 (cited in note 194) (arguing that the optimal time for an offer will depend in part on the amount of information available to the defendant about the likely outcome of the litigation). 
Making Rule 68 offers ineffective after final judgment eliminates the plaintiff's incentive to keep courts uninformed. Now, the plaintiff has a reason to inform the court: the judge may postpone ruling on summary judgment until after the offer expires, giving the plaintiff a proper chance to accept or reject it. Presumably, the court will value a chance to dispose of the case without devoting additional resources to it. And disposition through settlement will ensure the outcome is more agreeable to both parties-a better outcome from the court's perspective.

Knowledge of a pending offer also allows courts to exercise some discretion-either postponing a ruling to allow parties to reach their own resolution or quickly entering final judgment on the merits. Advocates for reforming Rule 68 have criticized its tendency to divorce a case's outcome from its actual merits. ${ }^{199}$ This criticism arguably becomes strongest in the context of full summary judgment, in which a plaintiff cannot prevail on the merits as a matter of law. With the knowledge of a pending Rule 68 offer, judges have the opportunity to weigh the likelihood and benefits of settlement against any possible need to rule quickly on the merits. For example, most courts will presumably view settlement as the best option for allowing parties to reach a mutually agreeable resolution with minimal judicial costs. However, if a pending offer is unlikely to induce settlement or the case is clearly frivolous, the court can simply ignore the offer and enter final judgment. This flexibility will help courts determine the most efficient course of action.

While it should improve the current status quo, this scheme is no panacea for arbitrary decisions or gamesmanship. Plaintiffs can still choose to keep the court uninformed or attempt to beat the court to an entry of final judgment on the docket-a determination completely independent of the case's merits. However, the court's ability to enter final judgment simultaneously with a grant of summary judgment makes it difficult for the plaintiff to prevail in this way-whether or not the court actually had a chance to consider the Rule 68 offer. ${ }^{200}$

This proposal may also allow the court to pressure the plaintiff into accepting an offer before the full fourteen-day period allowed under Rule 68 elapses. Yet, plaintiffs always make

199 See, for example, Jonathan T. Molot, How U.S. Procedure Skews Tort Law Incentives, 73 Ind L J 59, 112 (1997).

200 See Judgment Order, Day v Krystal Co, No 1:05-CV-00300 (ED Tenn filed Jan 24, 2007); Docket No 97-2959, Perkins v US West Communications, No 97-2959 (8th Cir filed July 21,1997$)$. 
Rule 68 determinations under time pressure and with limited information. At least this way, plaintiffs can attempt to avoid unfavorable time constraints by alerting the court and requesting more time.

3. The irrevocable nature of offers prevents parties from contracting around the problem.

Finally, parties might simply anticipate summary judgment and structure the terms of their Rule 68 offers to avoid conflicts. However, cases interpreting Rule 68 suggest this is not a viable solution. As the Perkins court noted, a shrewd defendant might condition acceptance of the offer upon the outcome of the motion for summary judgment, ${ }^{201}$ similar to a material-adverse-change clause that conditions acceptance on the maintenance of certain conditions in most commercial contracts. ${ }^{202}$ Rule 68 fails to address the addition of conditions to the offer, referring only to terms that the court must enter in the judgment upon acceptance. To date, no circuit court has considered an offer of judgment that conditioned acceptance upon a pending motion. Two circuit courts have allowed defendants to condition an offer upon acceptance by multiple plaintiffs, ${ }^{203}$ but this condition had no effect on the timing of acceptance or withdrawal, which distinguishes it from the condition suggested by Perkins. Other more extreme attempts to place conditions on a Rule 68 offer have received a more hostile reception. ${ }^{204}$

More importantly, the irrevocable nature of offers appears to rule out conditioning acceptance on a pending summary judgment motion. ${ }^{205}$ The condition potentially amounts to an impermissible revocation by a party, as discussed in Part I.B. Rule 68 sets an express fourteen-day period for acceptance that defendants cannot alter. Allowing the defendant to shorten that period through conditions would contradict the Rule's text and court rulings on impermissible withdrawals. This type of condition

201 Perkins, 138 F3d at 339.

202 See Kari K. Hall, How Big Is the MAC?: Material Adverse Change Clauses in Today's Acquisition Environment, $71 \mathrm{U}$ Cin L Rev 1061, 1063 (2003) ("[T] he [material adverse change] clause is normally one of the heavily negotiated parts of a merger agreement.").

203 See Lang v Gates, 36 F3d 73, 75 (9th Cir 1994); Amativ City of Woodstock, 176 F3d 952, 958 (7th Cir 1999).

204 See, for example, Frazier v Harris, 218 FRD 173, 174-75 (CD Ill 2003) (rejecting a condition that effectively gave the offeror the power to reject an acceptance).

205 See Wright, Miller, and Marcus, 12 Federal Practice and Procedure $\S 3002$ at 92 (cited in note 58) ("[An offer] must be unconditional."). 
could also open the door to other conditions and invite abuse. For example, a defendant could condition an offer of judgment on an event he knows will happen shortly thereafter. Once the offer is considered "withdrawn," Rule 68(d)'s cost-shifting consequences could be interpreted to punish a plaintiff who barely had time to consider accepting it. Instead of wading into this quagmire, courts should prohibit attempts to condition Rule 68 offers on the outcome of summary judgment.

\section{CONCLUSION}

Rule 68's notorious ambiguity often leaves courts adrift and contributes to its infrequent use by litigants. But when Rule 68 intersects with more definite rules and doctrines, courts have a chance to increase certainty and improve Rule 68's operation. This Comment illustrates that the conflict between Rule 68 and summary judgment can be resolved by reconsidering the assumption that Rule 68 operates like a contract. By interpreting Rule 68 as a stipulation and venerating the difference between summary and final judgments, courts can increase certainty in Rule 68's operation and, hopefully, promote greater use of the Rule as its drafters intended. 


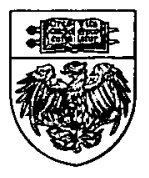

